\title{
METHODS FOR OVERCOMING DORMANCY IN Dinizia excelsa Ducke SEEDS ${ }^{1}$
}

\author{
ENIEL DAVID CRUZ², RAFAELA JOSEMARA BARBOSA QUEIROZ³ , JOSE EDMAR URANO DE CARVALHO ${ }^{4}$
}

\begin{abstract}
The impermeability of seed coat to water is common mechanism in Fabaceae seeds. Treatments to overcome hardseededness include scarification with sulphuric acid, scarification on abrasive surface and soaking in water among others. The objective of this study was to identify an effective method to overcome dormancy in Dinizia excelsa seeds. A pre-test (untreated seed) and three experiments were carried out: immersion of seeds in acid sulphuric for 10, 20, 30, 40, 50 and 60min (experiment 1); scarification on abrasive surface at the positions distal end, near of the mycrophyle and on the lateral tissue and tegument clipping at $1 \mathrm{~mm}$ of the distal end, near of the mycrophyle and on the lateral tissue (experiment 2); scarification on abrasive surface and immersion in water for 0 , 12, 24 and 48h (experiment 3). The experimental design was completely with four replications of 50 seeds for each treatment. The statistical analysis was carried out by ANOVA and regression analysis. Seedlings emergence on untreated seeds started on the $8^{\text {th }}$ day after sowing and reached $52.5 \%$ on the $1,709^{\text {th }}$ day. In general, the treatments to overcome dormancy increase emergence. Emergence was higher for seeds treated with sulphuric acid for 20 and 30min with emergence of $93.6 \%$ and $86.6 \%$, respectively. For seeds scarified on abrasive surface higher emergences were recorded for scarification on distal end, near of the mycrophyle and on the lateral, $82.7 \%, 74.3 \%$ and $75.7 \%$, respectively. Seeds scarified manually showed higher emergence when not immersed in water (75\%), or when immersed for 12 and $24 \mathrm{~h}(75 \%, 73.6 \%$ and $65.6 \%$, respectively). Immersion seeds in sulphuric acid for 20 and $30 \mathrm{~min}$ and scarification on abrasive surface of distal end are effective to overcome dormancy in $D$. excelsa.
\end{abstract}

Index terms: emergence speed index, hard seed, vigor

\section{MÉTODOS PARA SUPERAÇÃO DA DORMÊNCIA EM SEMENTES DE Dinizia excelsa Ducke}

\begin{abstract}
RESUMO - A impermeabilidade do tegumento de sementes a água é um mecanismo comum em Fabaceae. Tratamentos utilizados para superação da dormência consistem de escarificação com ácido sulfúrico, escarificação em superfície abrasiva, imersão em água entre outros. O objetivo deste trabalho foi identificar um método eficiente para superar a dormência em sementes de Dinizia excelsa
\end{abstract}

${ }^{1}$ Subbmited on 21/08/2008. Accpeted for publication on 30/04/2009.

${ }^{2}$ Agronomist., D.Sc., Embrapa Amazônia Oriental, Caixa Postal 48, 66017.

970, Belém, PA, Brazil. Email: eniel@cpatu.embrapa.br.

\footnotetext{
${ }^{3}$ Agronomist, Pos-Graduation on Plant Physiology, Rod. Prof. Paulo Donatto Castellane, S/N, 14884-900, Jaboticabal, SP, Brazil.
} 
e acompanhar seu processo de germinação ao longo do tempo . Foram conduzidos um pré-teste (sementes não escarificadas) e três experimentos: imersão em ácido sulfúrico por 10, 20, 30, 40, 50 e 60min (experimento 1); escarificação em superfície abrasiva na região distal, próximo a micrópila e na lateral da semente e corte de $1 \mathrm{~mm}$ no tegumento na região distal, próximo a micrópila e na lateral da semente (experimento 2); escarificação em superfície abrasiva e imersão em água por 0 , 12, 24 e 48h (experimento 3). O delineamento experimental foi inteiramente casualizado com quatro repetições de 50 sementes por tratamento. A análise estatística consistiu de ANOVA e análise de regressão. Sementes não escarificadas iniciaram a emergência de plântulas oito dias após a semeadura e atingiu 52,5\% aos 1.709 dias. Em geral, os tratamentos para superação da dormência promoveram a emergência das plântulas. A emergência foi maior nas sementes escarificadas com ácido sulfúrico por 20 e 30min com 93,6\% 86,6\%, respectivamente. Nas sementes submetidas a escarificação abrasiva e corte no tegumento, os melhores tratamentos foram escarificação na região distal, próximo à micrópila e na lateral da semente com $82,7 \%, 74,3 \%$ e 75,7\%, respectivamente. Sementes escarificadas em superfície abrasiva e imersas em água apresentaram melhores resultados quando o tempo de imersão foi de 12 e 24h, juntamente com as sementes não imersas, com emergência de 73,6 e 65,6\% e $75 \%$, respectivamente.A imersão de sementes em ácido sulfúrico por 20 e 30min e escarificadas em superfície abrasiva na região distal são tratamentos indicados para superar a dormência de $D$. excelsa.

Termos para indexação: índice de velocidade de emergência, semente dura, vigor.

\section{INTRODUCTION}

The impermeability of seed coat to water, known as physical dormancy, is a common mechanism in Fabaceae seeds (Rolston, 1978), caused by the presence of a cuticle and a layer of palisade cells or both (Copeland and McDonald, 1995). Physical dormancy causes slow and non-uniform germination (Cruz and Carvalho, 2006) and several pretreatments have been proved effective to overcome it. High, fast and uniform seed germination is a pre-requisite for the success of underutilized plant species (Travlos et al., 2007)

Treatments used to overcome physical dormancy include scarification with sulphuric acid, scarification by abrasive surface and soaking in water among others (Schmidt, 2007). The effectiveness of the treatment varies with species, concentration acid and treatment duration. The use of sulphuric acid has been recommended for species such as Tachigalia multijuga Benth. scarified for 20min (Borges et al., 2004), Enterolobium contortisiliquum (Vell.) Morong. for 5 to $10 \mathrm{~min}$ (Scalon et al., 2006), Astragalus hamosus L. for 60min (Patenè and Gresta, 2006) and Vigna spp. for 15 min (Wang et al., 2007). Scarification on abrasive surface has been effective on Bauhinia variegata L. (Martinelli-Seneme et al., 2006) and Hymenaea intermedia Ducke (Cruz et al., 2001a).

Dinizia excelsa Ducke, locally known as "angelimpedra", is native to the States of Pará, Rondônia, Roraima and Amazonas, in Brazil and Guiana (Ducke, 1949). The species produces a very dense wood, which is commercially prized (Parrotta et al., 1995).

The present study was designed to identify an effective method of breaking seed dormancy and establishing the inflexion point of the seedlings emergence curve in $D$. excelsa. The working hypothesis was that $D$. excelsa seedling emergence is improved when seeds are subjected to treatments to overcome dormancy.

\section{MATERIAL AND METHODS}

Dinizia excelsa seeds were collected from native forest in Belterra $\left(02^{\circ} 38^{\circ} \mathrm{S}\right.$; $\left.54^{\circ} 57^{\circ} \mathrm{W}\right)$ (pre-test) and

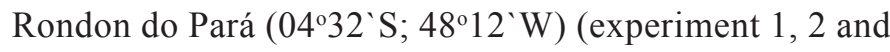
$3)$, State of Pará, Brazil. The experiments were carried out in Belém, Pará, Brazil $\left(1^{\circ} 28^{`} \mathrm{~S} ; 48^{\circ} 27^{`} \mathrm{~W}\right)$ to study $D$. excelsa seedling emergence. Seed moisture was quantified on uncut seeds in two replications of 20 seeds (untreated seed) and four replications of 20 seeds (experiment 1, 2 e 
3 ) in an oven set at $105 \pm 3^{\circ} \mathrm{C}$ for $24 \mathrm{hs}$ (Brazil, 1992), prior to the start experiment.

A pre-test to quantify the seedling emergence was carried out on untreated seeds. Emergence was quantified daily for 1,709 days in four replications of 100 seeds. The germination type and seedlings type were also determined according to Duke and Polhill (1981).

Experiment 1 - Effect of sulphuric acid. In this trial, the effect of immersing seeds in sulphuric acid (98\%) for $10,20,3040,50$ and $60 \mathrm{~min}$ on seedling emergence was evaluated. After scarification, seeds were washed for 10 minutes with running tap water to remove any traces of acid.

Experiment 2 - Effect of scarification on abrasive surface and tegument clipping. This trial evaluated the effect of manual seed scarification by electric emery (Ferrari ME 5A, $3450 \mathrm{rpm}$ ) on the following positions: distal end (Figure 1A), near of the mycrophyle (Figure 1B) and on the lateral tissue (Figure 1C). Also, the effect of clipping (using a nail clipper) on seedling emergence was studied in the following positions: clipping at $1 \mathrm{~mm}$ of the distal end (Figure 1A), $1 \mathrm{~mm}$ near of the mycrophyle region (Figure 1B) and $1 \mathrm{~mm}$ of the lateral tissue (Figure $1 \mathrm{C})$.

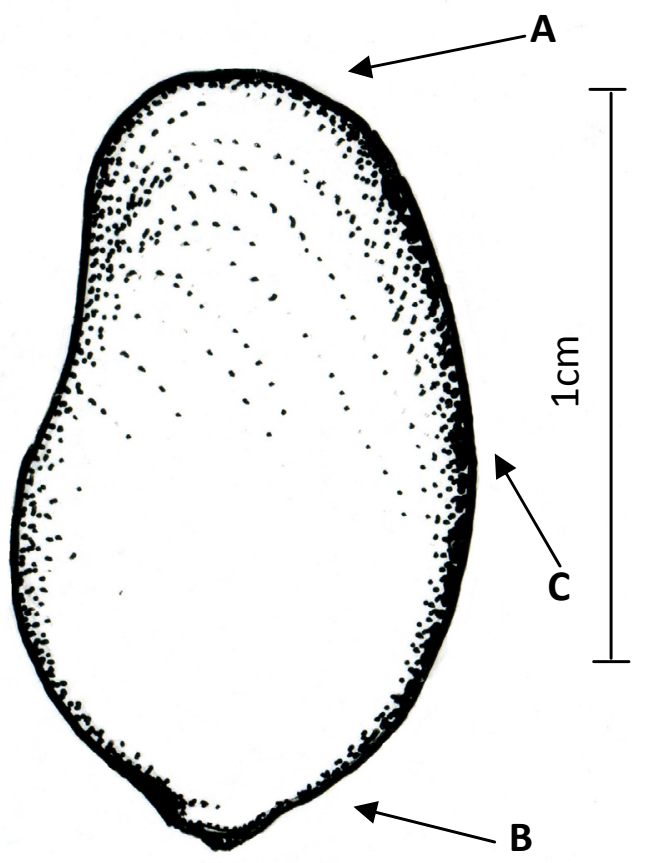

FIGURE 1. Dinizia excelsa seed. The arrow indicates the spot of manual scarification used in experiment 2.
Experiment 3 - Effect of scarification on abrasive surface and immersion in water. This trial investigated the effect of scarification on abrasive surface combined with immersion in water. Seeds were scarified by electric emery close to the mycrophyle region (Figure 1B). After scarification and immersing in water for $0,12,24$ and $48 \mathrm{~h}$ they were sown. In all experiments the treatments were compared with non-scarified seeds (control treatment).

Seeds were sown in a horizontal position in plastic trays $(22 \times 13 \times 6 \mathrm{~cm})$ at a depth of $1.0 \mathrm{~cm}$. The substrate used was a mixture of sand and sawdust (1:1), previously heated at $100^{\circ} \mathrm{C}$ for two hours to reduce microbial contaminants. The trays were irrigated every three days. All emergence tests were conducted in a laboratory under no temperature control and relative humidity (minimum and maximum temperature and relative humidity were $22^{\circ} \mathrm{C}$ and $29^{\circ} \mathrm{C}$, and $74 \%$ and $95 \%$, respectively).

The seedling emergence was noted daily. A seedling was considered as emerged when it showed the first pair of definitive leaves. The number of days to the emergence onset, i.e., the number of elapsed days from sowing until emergence of the first seed, emergence speed index (Maguire, 1962), hard seeds, dead seeds and abnormal seedlings were also quantified (Brasil, 1992).

The experimental design was completely randomized with four replications of 50 seeds for each treatment. The data were subjected to homogeneity of variance test (Bartlett test) and data were transformed (arcsin $\sqrt{(x+0.5) / 100}$, for percentage data, and $\log (x+1)$ for other variables) when necessary. The statistical analysis of emergence percentage was carried out by regression analysis. After the last count, ANOVA analyses were carried out for other variables and emergence. Treatment means were compared by Tukey`s test $(\mathrm{P} \leq 0.05)$. All analyses were performed by the software Statistica, $2^{\text {nd }}$ Edition (Statsoft, 1999). Transformed values were backtransformed for presentation.

\section{RESULTS AND DISCUSSION}

On the pre-test seed moisture content was $12.1 \%$ (fwb) and germination was epigeal and seedlings were phanerocotylar. Seedling emergence was non-uniform and slow, beginning eight days after sowing. The whole emergence process took 1,709 days, when emergence achieved $52.5 \%$. The emergence curve was quadratic, with most increase in emergence between the $8^{\text {th }}$ and the $197^{\text {th }}$ day (Figure 2). 


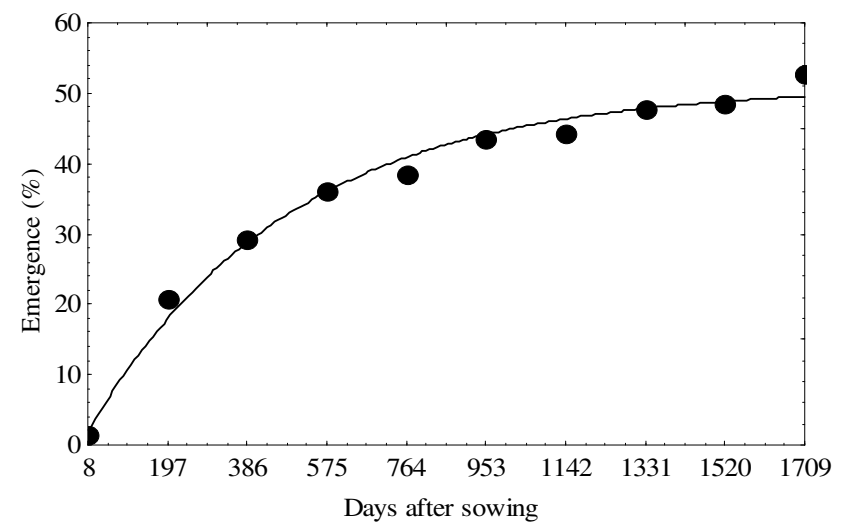

FIGURE 2. Seedling emergence in untreated Dinizia excelsa seeds.

Experiment 1 - Effect of sulphuric acid. Seed moisture content was $10.4 \%$ (fwb). Significant differences $(\mathrm{P} \leq 0.05)$ between treatments for all variables were observed. Seedlings required six to seven days to begin emergence, except in control in which emergence began 15.2 days after sowing (Table 1). All treatments to overcome dormancy promoted seedling emergence; however, immersion in acid for 20 and $30 \mathrm{~min}$ were the most efficient, with emergence of $93.6 \%$ and $86.6 \%$, respectively. Similar result was reported by Vastano
Júnior et al. (1983). Also, these treatments showed higher emergence speed index and less hard seeds. Seeds scarified for $10 \mathrm{~min}$ showed higher hard seed percentage (26\%) together with control treatment (99\%). Regression analyses were significant $(\mathrm{P} \leq 0.05)$ for all treatments, except for control. Treatments with higher emergence (immersion in acid for 20 and 30min) showed increase on emergence until the $11^{\text {th }}$ and the $15^{\text {th }}$ day, respectively, whereas for the others treatments the increase was detected during most evaluations (Figure 3). Regression equations and coefficients of determination of the all treatments are show on Table 2 .

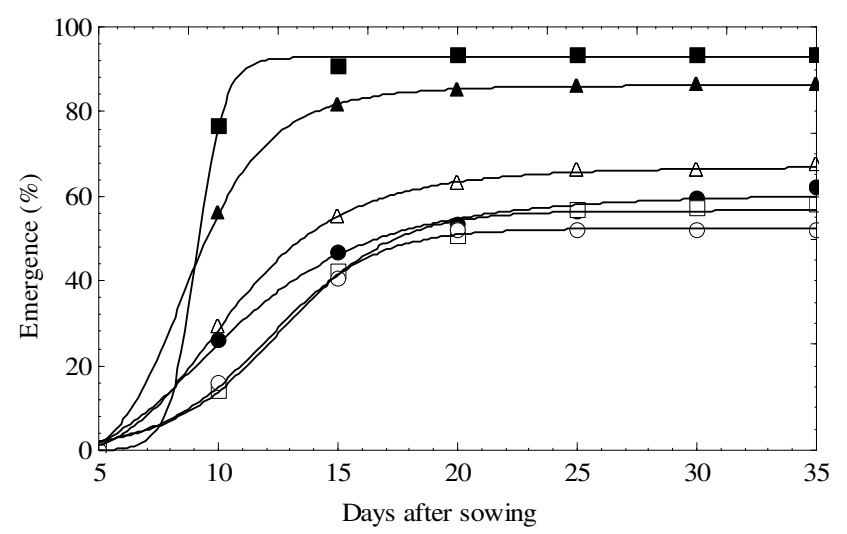

FIGURE 3. Immersion in sulphuric acid for $\bullet \mathbf{1 0}$, 20, $\Delta 30, \Delta 40, \square 50 \circ 60 \mathrm{~min}$, in Dinizia excelsa seeds.

TABLE 1. Number of days to emergence onset (DEO), emergence (E), emergence speed index (ESI), dead seeds (DS), hard seeds (HS) and abnormal seedlings (AS), in Dinizia excelsa seeds scarified with sulfuric acid.

\begin{tabular}{lcccccc}
\hline \multicolumn{1}{c}{ Treatments } & DEO & E (\%) & ESI & DS (\%) & HS (\%) & AS $(\%)$ \\
\hline Control & $15.2 \mathrm{~b}$ & $0.8 \mathrm{c}$ & $0.0690 \mathrm{~d}$ & $*$ & $99.0 \mathrm{c}$ & $*$ \\
Immersion in $\mathrm{H}_{2} \mathrm{SO}_{4}$ for $10 \mathrm{~min}$ & $7.0 \mathrm{a}$ & $62.4 \mathrm{~b}$ & $2.5786 \mathrm{c}$ & $4.7 \mathrm{a}$ & $26.0 \mathrm{~b}$ & $6.0 \mathrm{a}$ \\
Immersion in $\mathrm{H}_{2} \mathrm{SO}_{4}$ for $20 \mathrm{~min}$ & $6.3 \mathrm{a}$ & $93.6 \mathrm{a}$ & $5.2030 \mathrm{a}$ & $2.3 \mathrm{a}$ & $1.3 \mathrm{a}$ & $2.7 \mathrm{a}$ \\
Immersion in $\mathrm{H}_{2} \mathrm{SO}_{4}$ for $30 \mathrm{~min}$ & $6.0 \mathrm{a}$ & $86.6 \mathrm{a}$ & $4.3844 \mathrm{ab}$ & $5.9 \mathrm{a}$ & $1.5 \mathrm{a}$ & $6.0 \mathrm{a}$ \\
Immersion in $\mathrm{H}_{2} \mathrm{SO}_{4}$ for $40 \mathrm{~min}$ & $6.2 \mathrm{a}$ & $67.5 \mathrm{~b}$ & $2.9630 \mathrm{bc}$ & $20.5 \mathrm{~b}$ & $*$ & $12.0 \mathrm{ab}$ \\
Immersion in $\mathrm{H}_{2} \mathrm{SO}_{4}$ for $50 \mathrm{~min}$ & $6.0 \mathrm{a}$ & $58.1 \mathrm{~b}$ & $2.4177 \mathrm{c}$ & $21.2 \mathrm{~b}$ & $*$ & $20.5 \mathrm{~b}$ \\
Immersion in $\mathrm{H}_{2} \mathrm{SO}_{4}$ for $60 \mathrm{~min}$ & $6.0 \mathrm{a}$ & $55.4 \mathrm{~b}$ & $2.2050 \mathrm{c}$ & $29.5 \mathrm{~b}$ & $*$ & $14.7 \mathrm{ab}$ \\
\hline
\end{tabular}

Treatments means sharing the same letter within columns are not significantly different by Tukey test $(\mathrm{P}>0.05)$.

*Values omitted from variance analysis for being zero. 
TABLE 2. Regression equations and coefficients of determination for treatments to overcome dormancy in Dinizia excelsa seeds.

\begin{tabular}{|c|c|c|}
\hline \multicolumn{3}{|c|}{ Pre-test: Seedling emergence on untreated seeds } \\
\hline Treatment & $\begin{array}{ll}\text { Equation } \\
\end{array}$ & $\mathrm{R}^{2}$ \\
\hline Untreated seeds & $Y=49.8435(1.0206-\exp (-0.0021 x))$ & 0.99 \\
\hline \multicolumn{3}{|c|}{ Experiment 1: Effect of sulphuric acid } \\
\hline Treatments & $\begin{array}{l}\text { Equations } \\
\end{array}$ & $\mathrm{R}^{2}$ \\
\hline Imersion for $10 \mathrm{~min}$ & $Y=-1.544(5539.916)+60.893\left(x^{3.617}\right) / 5539.916+x^{3.617}$ & 0.99 \\
\hline Imersion for $20 \mathrm{~min}$ & $\mathrm{Y}=92.781 / 1+6282117.4(\exp (-1.721 \mathrm{x}))$ & 0.99 \\
\hline Imersion for $30 \mathrm{~min}$ & $Y=-1.498(235390.7)+86.3\left(x^{5.648}\right) / 235390.7+x^{5.648}$ & 0.99 \\
\hline Imersion for $40 \mathrm{~min}$ & $Y=-1.025(40720.321)+67.118\left(x^{4.495}\right) / 40720.321+x^{4.495}$ & 0.99 \\
\hline Imersion for $50 \mathrm{~min}$ & $Y=56.651 / 1+213.871(\exp (-0.424 x))$ & 0.99 \\
\hline Imersion for $60 \mathrm{~min}$ & $\mathrm{Y}=52.407 / 1+218.558(\exp (0.447 \mathrm{x}))$ & 0.99 \\
\hline \multicolumn{3}{|c|}{ Experiment 2: Effect of manual scarification } \\
\hline Treatments & $\begin{array}{r}\text { Equations } \\
\end{array}$ & $\mathrm{R}^{2}$ \\
\hline Scarification on distal end & $Y=81.751 / 1+2920701.6(\exp (-1.247 x))$ & 0.99 \\
\hline Scarification near of the mycrophyle & $Y=72.507 / 1+187601.09(\exp (-1.031 x))$ & 0.99 \\
\hline Scarification on the lateral & $\mathrm{Y}=73.401 / 1+1303267.8(\exp (-1.572 \mathrm{x}))$ & 0.99 \\
\hline Clipped distal end & $Y=14.046 / 1+5926.792(\exp (-0.692 x))$ & 0.99 \\
\hline Clipped near of the mycrophyle & $\mathrm{Y}=41.751 / 1+2240593.1(\exp (-1.206 \mathrm{x}))$ & 0.99 \\
\hline Clipped on the lateral & $\mathrm{Y}=38.127 / 1+10287847.3(\exp (-1.155 \mathrm{x}))$ & 0.99 \\
\hline \multicolumn{3}{|c|}{ Experiment 3: Effect of manual scarification and immersion in water } \\
\hline Treatments & $\begin{array}{l}\text { Equations } \\
\end{array}$ & $\mathrm{R}^{2}$ \\
\hline Immersion in water for $0 \mathrm{~h}$ & $Y=71.327 / 1+2510.211(\exp (-0.663 x))$ & 0.99 \\
\hline Immersion in water for $12 \mathrm{~h}$ & $Y=-1.818(6184.563)+72.055\left(x^{3.582}\right) / 6184.563+x^{3.582}$ & 0.98 \\
\hline Immersion in water for $24 \mathrm{~h}$ & $\mathrm{Y}=-2.428(412.156)+72.028\left(\mathrm{x}^{2.244}\right) / 412.156+\mathrm{x}^{2.244}$ & 0.97 \\
\hline Immersion in water for $48 \mathrm{~h}$ & $\mathrm{Y}=-0.744(2148380.5)+38.416\left(\mathrm{x}^{5.644}\right) / 2148380.5+\mathrm{x}^{5.644}$ & 0.97 \\
\hline
\end{tabular}

Sulphuric acid has been reported as an effective method to overcome dormancy in hard coat seeds in species such as Bowdichia virgiloides Kunth (Smirdele and Sousa, 2003), Caesalpinia leiostachya (Benth.) Ducke (Biruel et al., 2007), Dimorphandra mollis Benth. (Hermansen et al., 2000), Mimosa caesalpiniaefolia Benth. (Bruno et al., 2001), Schizolobium amazonicum Huber ex Ducke (Cruz et al., 2007), Senna. siamea (Lam.) H.S. Irwin \& Barneby (Dutra et al., 2007) and Stylosanthes scabra Vogel (Araújo et al., 2002). However, exposure time to acid is critical and needs to be quantified for each species, since seeds exposed for a long period may be damaged (Schmidt, 2007). In the present study, seed soaked for 40,50 and 60min suffered reduction in emergence and increase in the percentage of dead seeds and abnormal seedlings, when compared with scarified seeds for 20 and $30 \mathrm{~min}$. This may be due to an excessive exposition of seeds to acid which damage the embryo. Kondo (1993) reported that Lotus corniculatus L. seeds soaked for $20 \mathrm{~min}$ or more in acid showed reduced germination and increase in abnormal seedlings and dead seeds percentage.

Experiment 2 - Effect of scarification by abrasive surface and tegument clipping. Significant differences $(\mathrm{P} \leq 0.05)$ between treatments for all variables were observed (Table 3 ). Seed scarified by abrasive surface and tegument clip required 8.2 to 9 days to begin emergence, while seeds from the control treatment required 26.3 days. Scarification by abrasive surface was most effective, 
with emergence ranging from $74.3 \%$ to $82.7 \%$. Also this treatment showed higher speed index and lower dead seeds percentage. For clipped seeds, emergence was affected by the clippings position, ranging from $14.2 \%$ (clippings on distal end) to $42 \%$ (clipping near the mycrophyle). In the tegument clipping treatments there was a high percentage of abnormal seedlings, ranging from $12 \%$ (clip near mycrophyle) to $54 \%$ (clipping on distal end). This was mainly due to permanence adhered tegument on cotyledons hindering seedling development. Regression analyses were significant $(\mathrm{P} \leq 0.05)$ for all treatments, except for control. Emergence increase until the $15^{\text {th }}$ day, the exception was for scarification on the lateral in which the increase was observed only until the $10^{\text {th }}$ day (Figure 4).

TABLE 3. Number of days to emergence onset (DEO), emergence (E), emergence speed index (ESI), dead seeds (DS), hard seeds (HD) and abnormal seedlings (AS), in Dinizia excelsa seeds scarified and clipped.

\begin{tabular}{lrrrrrr}
\hline \multicolumn{1}{c}{ Treatments } & DEO & E (\%) & ESI & DS (\%) & HS (\%) & AS (\%) \\
\hline Control & $26.3 \mathrm{~b}$ & $2.5 \mathrm{~d}$ & $0.0640 \mathrm{~d}$ & $*$ & $96.2 \mathrm{~b}$ & $*$ \\
Scarification distal end & $8.7 \mathrm{a}$ & $82.7 \mathrm{a}$ & $3.5859 \mathrm{a}$ & $10.7 \mathrm{ab}$ & $2.2 \mathrm{a}$ & $4.0 \mathrm{a}$ \\
Scarification near the mycrophyle & $8.2 \mathrm{a}$ & $74.3 \mathrm{a}$ & $3.1573 \mathrm{a}$ & $8.5 \mathrm{a}$ & $9.3 \mathrm{a}$ & $7.5 \mathrm{a}$ \\
Scarification on lateral & $8.2 \mathrm{a}$ & $75.7 \mathrm{a}$ & $3.1854 \mathrm{a}$ & $13.5 \mathrm{ab}$ & $5.3 \mathrm{a}$ & $5.5 \mathrm{a}$ \\
Clip of the distal end & $9.0 \mathrm{a}$ & $14.2 \mathrm{c}$ & $0.5665 \mathrm{c}$ & $31.5 \mathrm{bc}$ & $*$ & $54.0 \mathrm{~b}$ \\
Clip near the mycrophyle & $8.7 \mathrm{a}$ & $42.0 \mathrm{~b}$ & $1.7289 \mathrm{~b}$ & $46.0 \mathrm{c}$ & $*$ & $12.0 \mathrm{a}$ \\
Clip of the lateral & $8.2 \mathrm{a}$ & $38.1 \mathrm{~b}$ & $1.5990 \mathrm{~b}$ & $42.0 \mathrm{c}$ & $*$ & $19.5 \mathrm{a}$ \\
\hline
\end{tabular}

Treatments means sharing same letter within columns are not significantly different by Tukey test $(\mathrm{P}>0.05)$.

* Values omitted from variance analysis for being zero.

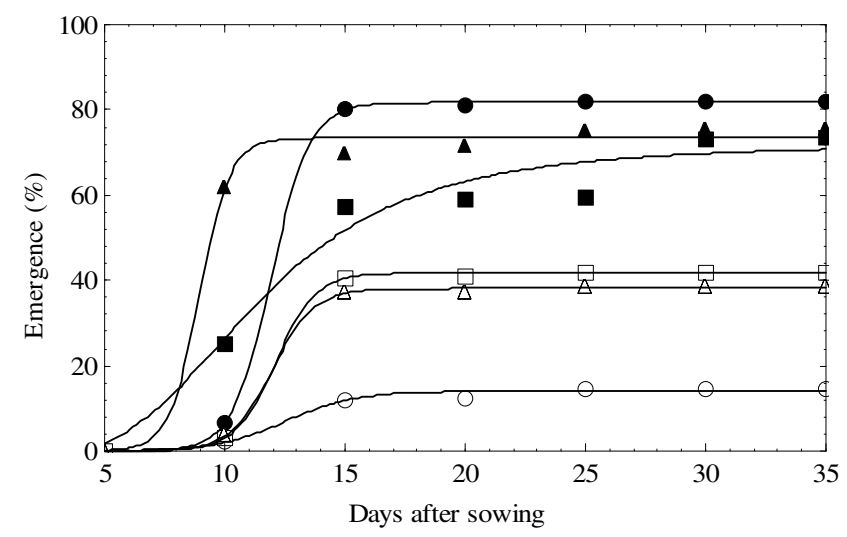

FIGURE 4. - Scarification on distal end, a near of mycrophyle, $\Delta$ on the lateral, and $\circ$ clipped distal end, $\Delta$ near of mycrophyle and $\square$ clipped on the lateral, in Dinizia excelsa seeds.

Seedlings emergence on seeds scarified on abrasive surface was higher than the one reported by Vastano Júnior et al. (1983) for the same species. This was probably due to genetic variation among plants (Borges et al., 2004; Koornneef et al., 2002). This scarification method has been recommended to overcome the physical dormancy in species such as $H$. intermedia (Cruz et al., 2001a), $S$. amazonicum (Cruz and Carvalho, 2006) and Trifolium riograndense Burkart (Suñé and Franke, 2006), however on applying this method it is necessary to avoid damage to the embryo (Perez, 2004). The lower emergence of clipped seeds compared to scarified seeds by abrasive surface, might be related to a more intense scarification of the clipped seeds. This scarification method may cause damage to cotyledons favoring the development of fungi, increasing the number of dead seeds and abnormal seedlings. Cruz et al. (2001b) reported increase on dead seeds and abnormal seedlings in Parkia nitida Miquel. when seeds were scarified by abrasive surface and not treated with fungicide.

Experiment 3 - Effect of manual scarification on abrasive surface and immersion in water. Significant differences $(\mathrm{P} \leq 0.05)$ between treatments for all variables were observed (Table 4). Emergence on scarified seeds started between the $6^{\text {th }}$ and the $7.5^{\text {th }}$ day after sowing, while on the control treatment emergence began after the 15.2 days. All treatments to overcome dormancy increase seedling emergence that ranged from $40.4 \%$ (immersion after $48 \mathrm{~h}$ ) to $75 \%$ (sowed immediately); while on control treatment it was $2.4 \%$. However, immersing seeds in water after manual scarification did not increase emergence, and when immersion period was $48 \mathrm{~h}$ was actually reduced. Increase 
in seedling emergence was probably caused by manual scarification, since seeds sowed immediately after manual scarification showed similar emergence to the ones that received manual scarification and sowed after 12 and $24 \mathrm{~h}$ and higher emergence when immersion lasted 48h. Similar performance was observed for emergence speed index. The increasing exposition to water after manual scarification increase seed death, mainly when seeds were soaked for $48 \mathrm{~h}$ (54.5\%). Abnormal seedling percentage was low, ranging from $4 \%$ to $8.5 \%$. Regression analyses were significant $(\mathrm{P} \leq 0.05)$ for all treatments, except for control. Emergence increase was observed until the $18^{\text {th }}$ day, for seeds sowed immediately. For the other treatments (except control), in general, increase on emergence was observed during most evaluations (Figure 5). Cruz et al. (2006) also reported the ineffectiveness of scarification on abrasive surface, followed soaking seeds in water to promote tropical tree seedling emergence.

TABLE 4. Number of days to emergence onset (DEO), emergence (E), emergence speed index (ESI), dead seeds (DS), hard seeds (HD) and abnormal seedlings (AS), in Dinizia excelsa seeds submitted to manual scarification and immersed in water.

\begin{tabular}{lrrrcrr}
\hline Treatments & DEO & E $(\%)$ & ESI & DS (\%) & HD $(\%)$ & AS $(\%)$ \\
\hline Control & $15.2 \mathrm{~b}$ & $2.4 \mathrm{c}$ & $0.1149 \mathrm{c}$ & $*$ & 97.5 & $*$ \\
Manual scarification + IS & $7.5 \mathrm{a}$ & $75.0 \mathrm{a}$ & $3.4918 \mathrm{a}$ & $17.0 \mathrm{ab}$ & $*$ & $8.5 \mathrm{a}$ \\
Manual scarification + I12h & $6.2 \mathrm{a}$ & $73.6 \mathrm{a}$ & $3.2350 \mathrm{a}$ & $22.5 \mathrm{~b}$ & $*$ & $4.0 \mathrm{a}$ \\
Manual scarification + I24h & $6.0 \mathrm{a}$ & $65.6 \mathrm{a}$ & $2.8582 \mathrm{a}$ & $30.5 \mathrm{~b}$ & $*$ & $4.0 \mathrm{a}$ \\
Manual scarification + I48h & $6.2 \mathrm{a}$ & $40.4 \mathrm{~b}$ & $1.5617 \mathrm{~b}$ & $54.5 \mathrm{c}$ & $*$ & $5.0 \mathrm{a}$ \\
\hline
\end{tabular}

Treatments means sharing same letter within columns are not significantly different Tukey test $(\mathrm{P}>0.05)$.

IS (mechanical scarification and immediate sowing); I12h, I24h and I48h (mechanical scarification and immersion in water for $12 \mathrm{~h}, 24 \mathrm{~h}$ and $48 \mathrm{~h}$, respectively).

* Values omitted from variance analysis for being zero.

\section{CONCLUSIONS}

The immersion of seeds in sulphuric acid for 20 and $30 \mathrm{~min}$ and scarification on abrasive surface of the distal end are effective to overcome dormancy in $D$. excelsa.

\section{AKNOWLEDGEMENTS}

To Moacyr B. Dias-Filho for the manuscript suggestions.

\section{REFERENCES}

ARAÚJO, E.F.; ARAÚJO, R.F.; SILVA, R.F. da; GALVÃO, J.C.C. Superação da dormência em sementes de Stylosanthes scabra Vogel e seu efeito na germinação. Revista Brasileira de Sementes, v.24, n.2, p.70-76, 2002.

BIRUEL, R.P.; AGUIAR, I.B. de; PAULA, R.C.de. Germinação de sementes de pau-ferro, submetidas a diferentes condições de armazenamento, escarificação química, temperatura e luz. Revista Brasileira de Sementes, v.29, n.3, p.1-9, 2007.

BORGES, E.E. de L.; RIBEIRO JÚNIOR, J.I.; REZENDE, S.T. de; PEREZ, S.C.J.G.A. Alterações fisiológicas em sementes de Tachigalia multijuga (Benth.) (momoneira) relacionadas aos métodos para superação da dormência. Revista Árvore, v.28, n.3, p.317-325, 2004.

BRASIL. Ministério da Agricultura e Reforma Agrária. Secretaria Nacional de Defesa Agropecuária. Departamento Nacional de Produção Vegetal. Coordenação de Laboratório Vegetal. Regras para Análise de Sementes. Brasília, DF, $1992.365 \mathrm{p}$.

BRUNO, R.L.A.; ALVES, E.U.; OLIVEIRA, A.P.; PAULA, R.C. Tratamentos pré-germinativos para superar a dormência em sementes de Mimosa caesalpiniaefolia Benth. Revista Brasileira de Sementes, v.23, n.2, p.136-143, 2001.

COPELAND, L.O.; MCDONALD, M.B. Principles of seed science and technology. New York: Chapman \& Hall, 1995. p.127-152. 
CRUZ, E.D.; CARVALHO, J.E.U. de. Methods of overcoming dormancy in Schizolobium amazonicum Huber ex Ducke (Leguminsae - Caesalpinioideae) seeds. Revista Brasileira de Sementes, v.28, n.3, p.108-115, 2006.

CRUZ, E.D.; CARVALHO, J.E.U. de; LEÃO, N.V.M. Métodos para superação da dormência e biometria de frutos e sementes de Parkia nitida Miquel. (Leguminsae - Mimosoideae). Acta Amazonica, v.31, n.2, p.167-177, $2001 b$.

CRUZ, E.D.; CARVALHO, J.E.U. de; QUEIROZ, R.J.B. Scarification with sulphuric acid of Schizolobium amazonicum Huber ex Ducke seeds - Fabaceae. Scientia Agricola, v.64, n.3, p.308-313, 2007.

CRUZ, E.D.; MARTINS, F. de O.; CARVALHO, J.E.U. de. Biometria de frutos e sementes e germinação de jatobácuruba (Hymenaea intermedia Ducke, Leguminosae Caesalpinioideae). Revista Brasileira de Botânica, v.24, n.2, p.161-165, 2001a.

DUCKE, A. Notas sobre a flora neotropica - II: as leguminosas da Amazônia Brasileira. Belém: Instituto Agronômico do Norte, 1949. 247p. (Boletim técnico,18).

DUKE, J.A.; POLHILL, R.M. Seedlings of leguminosae. In: POLHILL, R.M.; RAVEN, P.H. (Ed.). Advances in legumes systematics. Kew: Royal Botanic Gardens, 1981.v.2, p.941949.

DUTRA, A.S.; MEDEIROS FILHO, S.; TEÓFILO, E.M.; DINIZ, F.O. Germinação de sementes de Senna siamea (Lam.) H.S. Irwin \& Barneby - Caesalpinaceae). Revista Brasileira de Sementes, v.29, n.1, p.160-164, 2007.

HERMANSEN, L.A.; DURYEA, M.L.; WHITE, T.L. Variability in seed coat dormancy in Dimorphandra mollis. Seed Science and Technology, v.28, n.3, p.567-580, 2000.

KONDO, T. Promotion of hard-seed germination in Lotus corniculatus var. japonicus for use in amenity grasslands. Seed and Seed Technology, v.21, p.611-619, 1993.

KOORNNEEF, M.; BENTSINK, L.; HILHORST, H. Seed dormancy and germination. Current Opinion in Plant Biology, v.5, n.1, p.33-36, 2002.

MAGUIRE, J.D. Speed of germination: aid in selection and evaluation for seedling emergence and vigour. Crop Science, v.2, p.176-177, 1962.

MARTINELLI-SENEME, A.; POSSAMAI, E.; SHUTA, L.R.; VANZOLINI, S. Germinação e sanidade de sementes de Bauhinia variegata. Revista Árvore, v.30, n.5, p.719724, 2006.

PARROTTA, J.A.; FRANCIS，J.K.; ALMEIDA， R.R. de. Trees of the Tapajós: a photographic field guide. Rio Piedras: USDA Forest Service - International Institute of Tropical Forestry, 1995. 370p. (USDA Forest Service. General Technical Report IITF, 1).

PATANE, C.; GRESTA, F. Germination of Astragalus hamosus and Medicago orbicularis as affected by seedcoat dormancy breaking techniques. Journal of Arid Environments, v.67, n.1, p.165-173, 2006.

PEREZ, S.C.J.G. de A. Envoltórios. In: FERREIRA, A.G.; BORGHETTI, F. Germinação: do básico ao aplicado. Porto Alegre: Artmed, 2004. p.125-134.

ROLSTON, M.P. Water impermeable seed dormancy. The Botanical Review, v.44, n.3, p.365-396, 1978.

SCALON, S. de P.Q.; MUSSURY, R.M.; GOMES, A.A.; SILVA, K.A.; WATHIER, F.; SCALON FILHO, H. Germinação e crescimento inicial de orelha-de-macaco (Enterolobium contortisiliquum (Vell.) Morong.): efeito de tratamentos químicos e luminosidade. Revista Árvore, v.30, n.4, p.529-536, 2006.

SCHMIDT, L. Seed dormancy and presowing treatment. In: Tropical forest seed. New York: Springer-Verlag, 2007. p.198-245.

SMIRDELE, O.J.; SOUSA, R. de C.P. de. Dormência em sementes de paricarana (Bowdichia virgiloides Kunth - Fabaceae - Papilionoideae). Revista Brasileira de Sementes, v.25, n.1, p.72-75, 2003.

STATSOFT. Statistica for windows. 2.ed. Tulsa: Statsoft. 1999. (General conventions and statistics).

SUÑÉ, A.D.; FRANKE, L.B. Superação de dormência e metodologias para testes de germinação em sementes de Trifolium riograndense Burkart e Desmanthus depressus Humb. Revista Brasileira de Sementes, v.28, n.3, p.29-36, 2006.

TRAVLOS, I.S.; ECONOMOU, G.; KARAMANOS, A.I. Germination and emergence of the hard seed coated Tylosema esculetum (Burch) A. Schreib in response to different presowing seed treatments. Journal of Arid Environments, v.68, n.3, p.501-507, 2007.

VASTANO JÚNIOR, B.; BARBOSA, A.P.; GONÇALVES, A.N. Tratamentos pré-germinativos de sementes de espécies florestais amazônicas. I - Angelim-pedra (Dinizia excelsa Ducke - Leguminosae, Mimosoideae). Acta Amazônica, v.13, n.2, p.413-419, 1983.

WANG, Y.R.; HANSON, J.; MARIAN, Y.W. Effect of sulphuric acid pretreatment on break hard seed dormancy in diverse accessions of five Vigna species. Seed Science and Technology, v.35, n.3, p.550-559, 2007. 